\title{
Breve história da Igreja do Nazareno: suas origens, heranças e chegada ao Brasil*
}

\author{
Brief history of the Church of the Nazarene: \\ its origins, heritages and arrival in Brazil
}

\section{Breve historia de la Iglesia del Nazareno: sus orígenes, legados y llegada a Brasil}

\author{
Vinicius Couto*
}

\begin{abstract}
RESUMO
A Igreja do Nazareno é uma denominação evangélica fundada entre 1907 e 1908 a partir de uma fusão de três denominações do Movimento de Santidade. Com heranças wesleyanas, fletcherianas e palmerianas, a Igreja do Nazareno tem atuado com uma perspectiva holística da missio Dei em mais de 160 países. Apesar de ter tal abrangência geográfica, a história denominacional ainda não é muito bem conhecida nos países de língua portuguesa. Por isso, o presente artigo apresenta um pouco desta narrativa histórica demonstrando suas origens e heranças, bem como sua chegada em solo brasileiro.

Palavras-chave: Igreja do Nazareno; John Wesley; Phineas Bresee; Phoebe Palmer; Movimento de santidade.
\end{abstract}

\begin{abstract}
The Church of the Nazarene is an evangelical denomination founded between 1907 and 1908 from a merger of three denominations of the Holiness Movement. With Wesleyan, Fletcherian and Palmerian heritages, the Church of the Nazarene has been acting with a holistic view of missio Dei in more than 160 countries. Despite having such geographical coverage, denominational history is still not very well known in Portuguese-speaking countries. Therefore, the present article presents some of this historical narrative demonstrating its origins and legacies, as well as its arrival on Brazilian soil.

Keywords: Church of the Nazarene; John Wesley; Phineas Bresee; Phoebe Palmer; Holiness movement.

\footnotetext{
RESUMEN

La Iglesia del Nazareno es una denominación evangélica fundada entre 1907 y 1908 a partir de una fusión de tres denominaciones del Movimiento de Santidad. Con las herencias wesleyanas, fletcherianas y palmerianas, la Iglesia del Nazareno ha actuado con una visión holística de missio Dei en más de 160 países. A pesar de tener tal cobertura geográfica, la historia denominacional aún no es muy conocida en los países de habla portuguesa. Por lo tanto, el presente artículo presenta parte de esta narrativa histórica que demuestra sus orígenes y legados, así como su llegada al suelo brasileño.

Palabras clave: Iglesia del Nazareno; John Wesley; Phineas Bresee; Phoebe Palmer; Movimiento de santidade.
}

* O presente trabalho foi realizado com apoio da Coordenação de Aperfeiçoamento de Pessoal de Nível Superior - Brasil (CAPES) - Código de Financiamento 001.

** Doutorando em Ciências da Religião pela Universidade Metodista de São Paulo (Umesp), pesquisador do Grupo de Pesquisa RIMAGO e bolsista CAPES. E-mail:
\end{abstract} prviniciuscouto@yahoo.com.br 


\section{Introdução}

O ano de 2018 foi especial para o povo nazareno. Nesse ano foi comemorado, simultaneamente, 110 anos de sua fundação e 60 anos no Brasil. A Igreja do Nazareno é uma denominação evangélica comissionada a fazer discípulos à semelhança de Cristo em todas as nações e que proclama a santidade bíblica. Embora tenha pouco mais de um centenário, sua história remonta ao reavivamento wesleyano do século XVIII, quando o despertamento de santidade alastrou-se pela Inglaterra, promovendo transformação na sociedade e nas regiões circunvizinhas. Além disso, a Igreja do Nazareno não se apresenta como um organismo autônomo ou restauracionista, mas como um "ramo da Igreja de Cristo 'una, santa, universal e apostólica"” (Manual da Igreja do Nazareno, 2017-2021, p. 8).

Apesar da data comemorativa e do marco histórico, a denominação ainda estava em falta com uma publicação de língua portuguesa que trouxesse detalhes históricos e outras informações relevantes sobre sua formação e aspectos identitários. Essa lacuna literária foi suprida em 2018, quando foi publicada a obra Uma igreja do povo e para o povo. A curiosidade disso é que o curso de teologia do Seminário Teológico Nazareno do Brasil possui a disciplina "História da Igreja do Nazareno" em sua grade curricular. Como lecionar, portanto, essa matéria sem referências literárias publicadas no país? O sílabo da disciplina, uma espécie de ementa curricular, apresenta algumas obras em inglês e uma em espanhol à guisa de bibliografia básica e complementar. Entretanto, o acesso a tais literaturas não é fácil e poucos professores dos polos do Seminário falam e/ou leem inglês. Deste modo, as aulas eram baseadas nas antigas classes ministradas pelos missionários norte-americanos e pioneiros, o que deixou de lado, inconscientemente, muitas informações formativas desta denominação.

A Igreja do Nazareno nasceu, apesar de muitas dissidências da Igreja Metodista Episcopal, de uma união de vários grupos do movimento de santidade estadunidense. Por isso, o presente artigo apresenta as principais heranças históricas da Igreja do Nazareno: em primeiro lugar, a herança wesleyana, que além de ser reconhecida pela teologia de santidade, entendia uma santidade prática e holística, que se preocupava com a sociedade, ponto marcante em todos os grupos de santidade que se fundiram entre os anos 1907 e 1908. Esse é um dos pontos mais marcantes do reavivamento wesleyano, mas que no contexto latino-americano, a Igreja do Nazareno deixou de enfatizar pensando numa santidade deontológica; outra herança importante é a phoeberiana, cuja "teologia do Altar", altamente influenciada pelo pensa- 
mento fletcheriano, formou muito da atual teologia nazarena; finalmente, é importante destacar a diferença entre a perfeição cristã, defendida por John Wesley, do perfeccionismo cristão, defendido pelo pelagianismo de Finney.

\section{$O$ avivamento wesleyano}

John Wesley (1703-1791) foi um clérigo da Igreja Anglicana, um dos organizadores de uma reunião de universitários que tinha por finalidade praticar a piedade, estudos bíblicos e missões urbanas. Os membros desse grupo, iniciado em 1729 na Universidade de Oxford, se reuniam para estudar a Bíblia e orar, além de visitarem orfanatos, hospitais e presídios. Sobre o início dessas reuniões e seus propósitos, o próprio Wesley registrou que: "Em novembro de 1729, data em que fui residir em Oxford, meu irmão [Charles], outros dois jovens cavalheiros [Morgan e Kirkham] e eu fizemos um acordo de nos reunirmos três ou quatro vezes por semana", de modo que "nos domingos à noite, líamos sobre teologia, e nas outras noites, os clássicos gregos e latinos" (WESLEY, 1996, p. 271). Esse grupo enfatizava dois elementos considerados não paralelos e nem mesmo paradoxais, mas simbióticos: a ortodoxia e a ortopraxia. ${ }^{1}$

Para Wesley, a crença correta precisava impulsionar o cristão para obras de caridade, de amor ao próximo e vice-versa. As obras não podiam ser um fim em si mesmas, pois não justificam o ser humano de seus pecados. Entretanto, a ênfase exacerbada no princípio sola gratia et fides (somente pela graça mediante a fé) da Reforma, também errava o alvo ao desprezar as boas obras. O equilíbrio, para Wesley, estava no entendimento de que, embora as obras não salvem ninguém, são deveres naturais de todo salvo, pois como afirmou o apóstolo Paulo, "somos feitura sua, criados em Cristo Jesus para as boas obras, as quais Deus preparou para que andássemos nelas" (Efésios 2:10). Seguindo aqueles dois princípios (ortodoxia e ortopraxia), o cristão estaria obedecendo aos dois maiores mandamentos da Lei, isto é, de amar a Deus com toda força, alma, coração e ao próximo como a si mesmo (Mateus 22:34-40). Wesley até usava esse conceito como uma das definições para a doutrina mais enfatizada por ele, a saber, a perfeição cristã: "a Perfeição Cristã é o amor a Deus e ao próximo" (WESLEY, 1984, p. 52).

Ortodoxia é o ensino correto, ao passo que ortopraxia é a prática correta. Por um lado, um cristão não deveria negligenciar as raízes de sua fé, por isso, é preciso estuda-la e entender seus fundamentos. Por outro, um cristão não deveria ficar apenas imerso em livros, ideias, intelecto e abstração. 
Além de teólogo e presbítero da Igreja Anglicana, Wesley foi um importante avivalista e muitas vezes é até mais conhecido por tal ministério. Ele exerceu grande influência na Inglaterra, levando a mensagem do Evangelho para as pessoas em praça pública. Muitas delas se arrependiam de seus pecados. Algumas pessoas caíam desmaiadas, mas se levantavam, posteriormente, com um grande prazer de paz que tomava conta delas, as quais alegavam estar limpas do pecado (GONZÁLEZ, 2011, p. 348). Para acolher a grande multidão de pessoas que eram atraídas pela mensagem bíblica de santidade, Wesley implementou pequenos grupos espalhados pelo Reino Unido, pois muitas delas estavam saindo das zonas rurais para a cidade em função da revolução industrial e não encontrariam acolhimento nas paróquias, pois estas eram elitizadas. Esses grupos ficaram conhecidos como Sociedades Metodistas e contaram com a participação de leigos e até mesmo de mulheres, na condução das reuniões. Wesley é uma figura importante para a tradição da Igreja do Nazareno e de outras denominações tradição metodista e do movimento de santidade. ${ }^{2}$

\section{A Igreja Metodista Episcopal}

Além de empreender seus esforços nas sociedades metodistas no Reino Unido, Wesley também mantinha contato com alguns evangelistas ingleses que estavam nas colônias da América do Norte. Muitos desses evangelistas tiveram contato direto com Wesley, tais como Thomas Coke e Francis Asbury. Entre 1765 e 1783 ocorreu nas colônias a "Revolução Americana". No final dessa revolução, 13 colônias ganharam independência da Inglaterra. Dentre as relações rompidas pela independência estava a matriz religiosa; isso afetou diretamente o anglicanismo das colônias, uma vez que não havia clérigos suficientes para administrar os sacramentos e cuidar dos neófitos. Dada essa dificuldade, surgiu a necessidade da organização de uma nova denominação protestante em solo norte-americano. Embora o anglicano Wesley fosse contra a criação de uma denominação, as novas demandas levaram-no a repensar seu posicionamento e a aprovar a criação da Igreja Metodista Episcopal. Por isso, "esta igreja foi fundada em 1784 durante a Christmas Conference (Conferência de Natal) realizada na Loveley Lane Chapel, localizada em Baltimore, Maryland" e "os

Para conhecer melhor sua vida, sugiro a leitura de HEITZENRATER, 1996 e LELIÈVRE, 1997. Para entender sua teologia, são imprescindíveis as leituras de COLLINS, 2010; NOBLE, 2015; RUNYON, 2002. Para uma abordagem de Wesley e de sua teologia numa perspectiva mais nazarena, ver COUTO, 2018a. 
Superintendentes fundadores foram Thomas Coke [1747-1814] (que fora ordenado por John Wesley para esta função do episcopado)" e "Francis Asbury [1745-1816] (que fora ordenado na conferência supracitada por Coke a pedido de Wesley, e que estava envolvido com o itinerantismo wesleyano desde 1763)" (COUTO, 2018b, p. 34).

A Igreja Metodista Episcopal (IME) seguiu com os aspectos identitários do movimento metodista inglês: a ênfase na mensagem bíblica de santidade e o engajamento social. Asbury, por exemplo, seguiu com a visão inclusivista dos negros em seu ministério, algo que seu mentor, John Wesley, também foi bastante engajado em seu posicionamento contra a escravidão. No ministério de Asbury, Henry Hosier (que ganhou a alcunha de Black Harry), foi o primeiro negro a pregar numa congregação de brancos e ordenou-o como Diácono em 1800. Além de Hosier, Asbury também ordenou Richard Allen, na Filadélfia, como o primeiro Presbítero negro dos Estados Unidos.

\section{O metodismo norte-americano}

Com a organização da IME nos Estados Unidos, a mensagem de santidade se alastrou por aquele país. Uma programação que ajudou na difusão dessa mensagem foi o Camp Meeting, uma espécie de retiro que continha reuniões por vários dias, havendo a necessidade de um acampamento para comportar a todos os participantes. Esse retiro foi realizado por presbiterianos e metodistas no outono de 1800, mas depois se tornou uma das principais estratégias de evangelismo e de avivamento da IME, que adaptou a programação para a sua realidade. Uma segunda estratégia missional daquele tempo foi a prática de circuitos, isto é, regiões formadas por pequenas cidades circunvizinhas em que o evangelista e/ou pastor faziam cultos, visitas e administravam os sacramentos. A junção dos circuitos com os Camp Meetings foi muito produtiva, tanto que Asbury reconheceu, em 1811, que aconteciam cerca de 500 reuniões desse tipo por ano, com uma participação anual de cerca de 10.000 pessoas (BULLÓN, 2011, p. 25-26).

Entretanto, com o rápido crescimento da IME, veio também o desafio de transmitir os elementos rudimentares de suas origens. Em 1825, Timothy Merrit (1775-1845) publicou o livro Treatise on Christian perfection, with directions for obtaining that state (Tratado sobre a perfeição cristã, com diretivas a respeito de como obter esse estado). Ele demonstrava a condição pecaminosa do ser humano e ensinava que a mudança viria com duas ações graciosas de Deus, a justificação e a santificação (perfeição cristã) 
e dizia que os cristãos deveriam "buscar [essa experiência] todos os dias, a toda hora e a todo momento" (MERRITT, 1832, p. 9). Merrit entendia a necessidade de enfatizar a doutrina de santidade e passou a editar um periódico chamado Guide to Christian Perfection (Guia para a Perfeição Cristã), em 1839. Logo no primeiro volume, ele escreveu um texto intitulado "What shall be done to revive the work of holiness in the Church?" ("O que pode ser feito para reviver a obra de santidade na Igreja?").

O movimento de santidade ainda era novo nos Estados Unidos, visto que a própria fundação da Igreja Metodista Episcopal ocorrera 45 anos antes, em 1784. Mesmo assim, Merritt se preocupava "com a consolidação e manutenção da identidade wesleyana e da doutrina bíblica de santidade. Seu periódico foi uma ferramenta importante para a disseminação e manutenção desta identidade teológica" (COUTO, 2018b, p. 49). Melvin Dieter, um estudioso do movimento de santidade, aponta que houve uma nova mistura desde os anos 1830, que, de acordo com ele, abarcava o pietismo histórico, o reavivalismo americano e a perfeição wesleyana (DIETER, 1996, p. 2-3). Essa mistura provocou o desdobramento de três grupos de santidade nos Estados Unidos. De acordo com Couto, "o primeiro [...] é o perfeccionista, da escola de Oberlin, liderado pelos evangelistas Charles Finney e Asa Mahan; o segundo seguia uma pneumatologia wesleyana modificada, liderado, dentre outras pessoas, pela Sra. Phoebe Palmer; e o terceiro seguia o wesleyanismo clássico" (COUTO, 2018b, p. 52).

\section{$O$ avivamento de santidade estadunidense: Charles Finney, Phoebe Palmer}

Conforme apontado no parágrafo anterior, o movimento de santidade se dividiu em três grupos. O primeiro deles entendia que a perfeição cristã era a possibilidade de não pecar. $\mathrm{O}$ principal expoente desse ramo foi $\mathrm{o}$ evangelista Charles Finney (1792-1875). Sua ideia de impecabilidade, ou perfeccionismo, residia no fato de negar o pecado original (FINNEY, 1846, p. 478). Entretanto, vale lembrar, em primeiro lugar, que a perfeição cristã ensinada por John Wesley não compactua desta perspectiva. Embora a nomenclatura "perfeição" pareça sugerir o contrário, vários autores, dentre os quais se encontra Theodore Runyon, citam que isso não passa de uma questão etimológica do grego. Runyon assevera que "Wesley entendia a santificação ou perfeição como um processo (teleiosis) e não como um estado completo (perfectus)" (RUNYON, 2002, p. 265). A segunda coisa a ser lembrada é que a negação do pecado original foi uma "heresia" defen- 
dida por um monge chamado Pelágio (360-420) e condenada oficialmente pela Igreja antiga nos concílios de Cartago (418 d.C.), de Éfeso (431 d.C.) e finalmente no Concílio de Orange II (529 d.C.).

O segundo grupo do movimento de santidade ocorreu com a Sra. Phoebe Palmer (1807-1874), uma leiga metodista que se interessou pelos aspectos identitários do metodismo, vindo a pesquisar sobre a vida e as obras de John Wesley. Além das obras de Wesley, suas fontes de estudo foram os livros de Fletcher e os comentários de Adam Clarke, além de outros metodistas primitivos. A maior influência teológica de Palmer se deu por meio dos escritos de John Fletcher (1579-1625), um amigo de Wesley que ensinava que o batismo no Espírito Santo (termo que era usado como sinônimo para a perfeição cristã) ocorria numa experiência distinta da conversão, ou seja, numa segunda obra da graça, chamada de "segunda bênção" por Fletcher. Influenciada pelos ensinos fletcherianos, a Sra. Palmer passou a propagar que a inteira santificação (outro termo sinônimo para perfeição cristã) ocorria após um período de inteira consagração, ou seja, quando o crente entregava todos os seus ídolos no altar de Deus, consagrando-se ao Senhor. Em função dessas terminologias, a teologia de Palmer ficou conhecida como "Teologia do altar".

Uma das maneiras como os teólogos metodistas e do movimento de santidade contemporâneos se referem à inteira santificação como segunda bênção é crise processo - crise. A primeira crise se dá em torno da compreensão da natureza caída do ser humano, que quando revelada gera o desejo ardente de ser justificado. Jesus disse que bem-aventurado são os que têm fome e sede de justiça, pois serão saciados (Mateus 5.6). A fome e a sede retratadas ali são de um momento extremo, de alguém que está, literalmente, isto é, sem usar de hipérbole, morrendo de sede ou fome pela justiça divina. Uma vez que a pessoa é justificada, ela tem paz com Deus (Romanos 5.1). Contudo, mesmo gozando desta paz, o cristão ainda não alcançou maturidade (perfeição, grego theleiosis) e nesse processo, acaba entrando numa nova crise, pedindo a Deus pelo batismo no Espírito Santo, que por sua vez, traz, como consequência, a purificação do coração (Atos 15.9) (COUTO, 2018b, p. 60).

A teologia de Palmer se popularizou entre os evangelistas metodistas. Contudo, por não ser a teologia oficial da IME, que cria que a perfeição cristã ocorria simultaneamente à justificação e adoção, muitos membros foram expulsos e criaram novas denominações que confessavam a segunda bênção.

Algumas das principais denominações a serem destacadas são: Church of God [Anderson] (Igreja de Deus - Anderson), fundada em 1881 por D. S. Warner; a Church of God [Holiness] (Igreja de Deus - Santidade), fundada em 1883. Nesse mesmo ano foi fundada a Bethren in Christ Menonite Church (Igreja Menonita Irmãos em 
Cristo). Em 1894 surgiu a United Evangelical Church (Igreja Evangélica Unida); em 1897, a International Apostolic Holiness Union (União Apostólica Internacional de Santidade), que, posteriormente, em 1922, mudou o nome para Pilgrim Church (Igreja Peregrina). Em 1901 surgiu a Holiness Methodist Church (Igreja Metodista de Santidade). Em 1907 nasceu a Church of God in Christ (Igreja de Deus em Cristo). Em 1935 a God's Missionary Church (Igreja de Deus Missionária). Três anos depois, surgiu o People's Christian Movement (Movimento Cristão do Povo), que mais tarde se tornou a People's Methodist Church (Igreja Metodista do Povo). Em 1946 surgiu a Evangelical Methodist Church (Igreja Metodista Evangélica). Nove anos mais tarde, 1955, foi fundada a Bible Missionary Church (Igreja Missionária da Bíblia). E, em 1968, com a união de duas denominações, a Evangelical United Brethren Church (Igreja Evangélica dos Irmãos Unidos) e a Methodist Church (Igreja Metodista), foi organizada a United Methodist Church (Igreja Metodista Unida) (COUTO, 2018b, p. 68).

Foi nesse ínterim que surgiu a Igreja do Nazareno. Inúmeros ministros metodistas que aderiram à teologia da segunda obra da graça, passaram a sofrer perseguições e retaliações. Alguns foram expulsos e outros se desligaram de suas igrejas. Inicialmente, não havia o interesse de criar novas denominações, mas a inexistência de outros grupos em que eles pudessem se associar proporcionou o surgimento de algumas denominações. Mesmo assim, aconteceram fusões entre as denominações recém-fundadas, visto que o objetivo não era criar dissidências, mas aliar os grupos que pensavam de maneira semelhante. A Igreja do Nazareno, por exemplo, é uma denominação que passou por esse processo. Grupos autônomos que nasceram em diferentes regiões dos Estados Unidos se uniram, posteriormente, visando a unidade eclesial, mas também uma maior eficiência na transmissão da mensagem bíblica de santidade. Para melhor compreensão, os grupos estão divididos abaixo em suas formações no Oeste, Leste e Sul dos Estados Unidos.

\section{As raízes da Igreja do Nazareno no Oeste dos Estados Unidos}

Em 1895 era fundada a Igreja do Nazareno na cidade norte-americana de Los Angeles. Os fundadores foram o ex-bispo metodista Phineas Bresee (1838-1915) e seu amigo J. P. Widney (1841-1938). Embora o nome desta denominação seja homônimo ao atual, não se trata exatamente da mesma denominação. Isso porque nos anos de 1907 e 1908, ocorreram duas Assembleias Gerais nas quais outras duas denominações, a saber, a Associação de Igrejas Pentecostais da América (fundada em 1895 e oriunda do Leste) e Igreja de Cristo de Santidade (fundada em 1901 e oriunda do Sul) fundiram-se dando origem à atual Igreja do Nazareno. 
Bresee nasceu em Franklin, condado de Delaware, que ficava na parte ocidental de Nova Iorque. Ele se converteu numa classe de estudos numa igreja metodista, em sua cidade natal, em fevereiro de 1856, e pouco tempo depois recebeu a licença de "Exortador", uma espécie de licença compatível com o que a Igreja do Nazareno utiliza atualmente como ministro local; uma licença que permite pregar e ajudar no trabalho pastoral sem, no entanto, administrar os sacramentos. No ano seguinte, ele se mudou com sua família para Millesburg, Iowa, onde começou a ajudar um velho pregador metodista em seus circuitos de quatro semanas (RASER, 2010, p. 167-168). Bresee teve sucesso nesse trabalho e iniciou seus estudos teológicos enquanto atuava na função de auxiliar o Bispo Metodista. Devido a seus esforços nos estudos e empenho como um evangelista, Bresee foi designado, em 1858, para dirigir seus circuitos solos na comunidade holandesa de Pella. No ano seguinte, ele foi ordenado diácono e também se casou com Mary Hibbard, irmã de um colega de classe e que fazia parte de uma família metodista muito conceituada (BANGS, 2013, p. 38-40).

Desde então, Bresee passou por diversos circuitos, como Grinnell e Galesburg, além de ter sido designado como Superintendente Distrital de Witersert, parte ocidental do estado de Iowa. Depois de dois anos na rotina pesada da superintendência, ele solicitou o seu rerorno ao pastorado, tendo sido designado para a igreja de Chariton, em Iowa (HALL, 2003, p. 171). Bresee estava muito sobrecarregado, mental e espiritualmente. Após pregar num culto durante o inverno de 1866-1867, ele fez um apelo para que os membros fossem à frente. Uma vez que ninguém foi, ele mesmo se dirigiu ao altar sozinho a fim de orar e recebeu um enchimento gracioso do Espírito Santo naquela noite, vindo a interpretar alguns anos depois como a sua experiência da inteira santificação (RASER, 2010, p. 169).

Em 1868 Bresee recebeu nova designação, desta vez para East Des Moines, onde a Sra. E. M. Wright passou pela experiência da inteira santificação num culto dirigido por Bresee. Ela, subitamente, sentiu seu corpo arder em chamas no local em que estava assentada enquanto Bresee pregava acerca da perfeição cristã (GIRVIN, 1916, p. 31). Nos anos seguintes, Bresee foi designado para outras cidades, passando por Council Bluffs, Red Oak e Clarinda. Após enfrentar algumas dificuldades financeiras, resolveu se mudar com sua família para Los Angeles, onde seu contato com o movimento de santidade efetivamente se consolidou. Bresee organizou uma programação que contou com a presença dos evangelistas William Eillian McDonald e George Watson, os quais vieram para uma série de campanhas de avivamento, no ano de 1885, e estiveram com Bresee por 
três semanas. Depois dessa série de reuniões, Bresee alegava estar com muita sede pela graça de Deus e destacou que "essa percepção crescia cada vez mais e se tornava cada vez mais intensa, até que meu coração anelava e começou a ir em busca da poderosa graça de Deus que fosse adequada para minhas necessidades" (BRESEE apud BRICKLEY, 1960, p. 37). Enquanto orava na sua casa, Bresee teve outra experiência revitalizadora. Ele mesmo relatou que viu uma bola de fogo se aproximando enquanto ouvia uma voz que dizia: "engula, engula". Seus lábios ficaram anestesiados por vários dias e sua vida espiritual foi reavivada (BRESEE apud BILLMAN, 2013, p. 75).

De Los Angeles Bresee fora designado para Pasadena e Asbury. Mas, com a chegada de John H. Vincent, em 1892, à presidência da Conferência da Califórnia do Sul, ele sofreu diversas perseguições, tendo sido deposto juntamente com outros colegas de ministério. Bresee foi designado para pequenas igrejas em Simpson e Boyle Heights e trabalhou paralelamente com uma missão paraeclesiástica chamada Peniel - um grupo que atuava junto aos marginalizados (pobres e negros) de Los Angeles. O grupo da missão crescia e Bresee se sentia desmotivado com sua denominação. Solicitou licença para atuar mais diretamente com a Missão Peniel, mas teve seu pedido negado. Depois de muita oração, ele decidiu se desligar da IME e se afiliou integralmente à Missão. Depois de servir como pastor da Missão Peniel por um ano, alguns amigos, interessados em promover a doutrina da santidade, alugaram um prédio e convidaram-no para pregar em seus cultos matutinos, bem como ao Dr. J. P. Widney para pregar às noites. No terceiro domingo de manhã, com a presença de 86 pessoas, eles organizaram a Igreja do Nazareno com o propósito declarado de pregar a santidade e levar o evangelho, prioritariamente, aos pobres. O nome "Igreja do Nazareno" foi sugerido por Widney, pois ele entendia que esse era o título mais humilde de Jesus e que identificava a nova congregação com a solidariedade que o Messias teve para com as massas oprimidas e marginalizadas (INGERSOL, 2014, p. 10-11). O primeiro documento oficial da nova denominação foi um caderno que anunciava as reuniões. Em um desses documentos consta uma mensagem que caracteriza a natureza da nova comunidade:

A Igreja do Nazareno é uma igreja simples, primitiva, uma igreja do povo e para o povo. Não carece de novas doutrinas, só as verdades antigas. Tenta desfazer-se de todas as formas supérfluas de igrejismo para voltar às palavras simples de Cristo. Não é uma missão mas uma igreja com uma missão. É um grupo unido de corações que já encontraram a paz com Deus e que em alegria saem para levar a mensagem 
das inescrutáveis riquezas do Evangelho de Cristo às almas desalentadas, sofredoras e doentes. A sua missão é para aqueles aos quais as lutas da vida têm marcado com a dor e para todos os corações que tem fome da limpeza do pecado (SMITH, 1962, p. 111).

A Igreja do Nazareno cresceu rapidamente e se espalhou por várias cidades do Oeste norte-americano. A liturgia era avivada, "os cultos eram fervorosos, e possuíam uma característica responsiva e dialógica", de modo que "era comum ouvir a congregação participando ativamente das mensagens e louvores, respondendo com 'amém' ou 'aleluia'”. Além disso, era comum que as pessoas "cantassem alto e que gritassem nas reuniões, tanto que os nazarenos chegaram a ser apelidados, em alguns locais, de noiserenes, um trocadilho no inglês, de noise (barulho) e nazarenes (nazarenos), ou seja, nazarenos barulhentos" (COUTO, 2018b, p. 89-90).

\section{As raízes da Igreja do Nazareno no Leste dos Estados Unidos}

A Igreja do Nazareno fundada pela missão paraeclesiástica pastoreada por Phineas Bresee seria unida mais tarde, em 1907, com outro grupo de santidade norte-americano chamado de Associação de Igrejas Pentecostais da América, cuja fundação se deu em 13 de abril de 1897. Diferentemente do movimento oriundo do Oeste, "a referida Associação foi fruto da união de diversas denominações holiness que nasceram durante o avivamento de santidade estadunidense" e "os dois grupos possuíam muito em comum: a ortodoxia e a ortopraxia armínio-wesleyana, bem como a crença na doutrina de santidade como segunda obra da graça" (COUTO, 2018b, p. 97).

A primeira igreja a dar origem à Associação de Igrejas Pentecostais da América, na costa Leste, foi a Igreja Evangélica do Povo, fundada em 21 de julho de 1887. Ela é considerada pelo historiador Floyd Cunningham como a mãe da Igreja do Nazareno no Leste (CUNNINGHAM, 2009, p. 57). Tudo começou quando o pastor da Igreja Metodista Episcopal de St. Paul, em Providence, Rhode Island, convidou a evangelista Lizzie Boyd para uma conferência de mensagens centradas na doutrina da inteira santificação. A mensagem acabou dividindo a igreja em dois grupos: um que não concordou com a segunda obra da graça e outro, que aderiu ao que interpretaram ser o "poder de Deus". Uma das pessoas empoderadas nessa reunião foi o leigo Fred Hilllery (1854-1937). Com a troca de pastores, a igreja enfraqueceu a mensagem da segunda obra da graça, pois os pastores posteriores não criam nessa doutrina; além disso, eles passaram a perseguir os membros que acreditavam. Hillery, ao invés de sair da igreja, 
fundou uma associação para-eclesiástica, a qual visava difundir a doutrina da inteira santificação, a South Providence Holiness Association - SPHA (Associação de Santidade de South Providence). Seu pastor, que já o havia excluído da função de Superintendente de Escola Dominical, não aceitou mais essa iniciativa e veio a exclui-lo da igreja. Diversos membros da IME não aceitaram a exclusão de Hillery, e cerca de 40 pessoas se reuniram com o intuito de iniciar uma nova denominação, cuja denominação adotada foi "Igreja Evangélica do Povo". A nova igreja se integrou a uma "fraternidade" composta por 13 igrejas e Hillery foi ordenado, em 15 de maio de 1889, pelos líderes desse grupo.

No ano seguinte, após a fundação da Igreja Evangélica do Povo, mais especificamente em 25 de novembro de 1888, um jovem evangelista de origem Batista, chamado C. Howard Davis, fundou a Igreja Missão em Lynn, uma cidade industrial que ficava ao norte de Boston, capital de Massachusetts. Em 1890 Davis abriu uma congregação em Malden, a Igreja Missão de Malden, assumindo-a como pastor, mas colocando a Sra. Anna Hanscome como sua ajudante. A Sra. Hanscome, ordenada em 1892, se tornou a primeira mulher a ser ordenada nas congregações que deram origem à Igreja do Nazareno (CUNNINGHAM, 2009, p. 59).

Nos dias 13 e 14 de março de 1890, os representantes das denominações apontadas, além de outras não elencadas nesta seção (mais três não identificadas nas fontes consultadas), reuniram-se e formaram a Associação Central Evangélica de Santidade (ACES), cujo propósito consistia em "promover a santidade bíblica por uma aliança e ação definida fortalecendo e estimulando os que, por causa de sua lealdade para a verdade divinamente inspirada, encontram-se sem os privilégios de um verdadeiro companheirismo" (COUTO, 2018b, p. 102).

Algo semelhante acontecia na região de Nova Iorque. William Howard Hoople (1868-1922) se converteu numa reunião presidida pelo famoso evangelista D. L. Moody. Hoople era um homem bastante engajado e piedoso. Experimentou a inteira santificação no ano de 1893, enquanto fazia seu devocional no escritório da empresa, lendo a Bíblia e orando. Tal experiência fez com que ele deixasse os negócios como secundário e passou a dedicar-se ao trabalho missionário. No ano seguinte, Hoople se juntou com seu amigo BeVier, e ambos começaram a procurar um local onde poderiam evangelizar os pobres. Foi quando, em 4 de janeiro de 1894, eles começaram uma missão num antigo salão. Esse salão, pouco tempo depois, não era suficiente para acomodar a quantidade de pessoas que participavam e eles tiveram que se mudar para um terreno baldio 
numa avenida chamada Útica, onde iniciaram as obras de um templo. Em 16 de dezembro de 1894, já no novo templo, a missão foi organizada com um total de trinta e dois membros fundadores, e recebeu o nome de Tabernáculo da Avenida Útica (INGERSOL, 2009, p. 84).

Hoople e seu amigo BeVier continuaram a abrir novas igrejas. No dia 24 de fevereiro foi organizado o Tabernáculo Pentecostal da Avenida Bedford e no dia 3 de Setembro de 1895, o Tabernáculo Pentecostal Emanuel. Como Hoople vinha de uma Igreja Congregacional, as três congregações eram autônomas na administração. Contudo, surgiu a ideia de estreitarem a cooperação entre as congregações visando alcançar resultados mais eficientes. Baseados nisso, os delegados das três congregações se uniram e organizaram, no dia 12 de dezembro de 1895, a Associação de Igrejas Pentecostais da América - AIPA (REDFORD; VAN NOTE, 1985, p. 85). Embora recém-chegado à AIPA, o ex-ministro metodista Hiram Reynolds (1854-1938), junto com Hoople, trabalhou apaixonadamente na colaboração de uma aproximação com os líderes da Associação Central Evangélica de Santidade (ACES) e "depois de várias conversas, os representantes de ambas associações, AIPA e ACES, reuniram-se em Massachusetts, no templo da Igreja Missão de Lynn, em 13 de abril de 1897", a fim de “consolidar a união e expandir a propagação da mensagem de santidade pelo mundo. Apesar do nome das duas associações serem bem distintos, os delegados da reunião optaram por conservar o nome Associação das Igrejas Pentecostais da América" (COUTO, 2018b, p. 109). Deste modo, "em 1898, Hiram Reynolds foi designado para trabalhar no comitê de missões em tempo integral. Em 1904, tornou-se Evangelista em tempo integral e Superintendente de Missões Estrangeiras da AIPA" (COUTO, 2018 b, p. 109). Durante o tempo em que ocupou essas funções, "ele se envolveu ativamente com a plantação de igrejas em território estrangeiro. O primeiro país a ser alcançado foi a Índia, e o segundo, Cabo Verde" (COUTO, 2018b, p. 109).

Redford e Van Note relatam que em 1907, a AIPA já estava bastante desenvolvida, contando com 47 igrejas organizadas e 2.371 membros; números expressivos obtidos em dez anos. Contudo, os planos eram de ampliarem ainda mais a eficácia da propagação da mensagem de santidade. Desde 17 de janeiro de 1906, o Comitê Missionário da AIPA pediu ao seu secretário que convidasse o Dr. Bresee para a sua reunião anual em abril. Ele não pôde ir, mas respondeu ao convite com uma carta, a qual abriu caminho para os próximos passos na aproximação. Pouco tempo depois, o casal Bresee, o casal Brown e E. A. Girven foram delegados do Oeste 
à reunião das Igrejas Pentecostais da América que se deu no Brooklyn, em abril de 1907. Além da AIPA e da Igreja do Nazareno, participavam delegados da Igreja de Cristo de Santidade. Os delegados da Associação de Igrejas Pentecostais da América e da Igreja do Nazareno reuniram-se em assembleia geral, em Chicago, de 10 a 17 de outubro de 1907, e esses dois grupos, que estavam em processo de união, concordaram quanto a um governo da igreja que equilibrava a necessidade de uma superintendência com a independência de congregações locais. Outra decisão foi uma mescla do nome das duas denominações, que resultou em Igreja Pentecostal do Nazareno. "Seguindo a diretriz de um governo que trouxesse equilíbrio, isto é, nada de episcopalismo e um sistema de governo que desse autonomia das igrejas locais", eles elegeram "Phineas F. Bresee e Hiram F. Reynolds como superintendentes gerais. Já a delegação da Igreja de Cristo de Santidade não fechou união nesta assembleia de 1907. Eles aguardaram, e apenas no ano seguinte consolidaram a união" (COUTO, 2018b, p. 111).

\section{As raízes da Igreja do Nazareno no Sul dos Estados Unidos}

O grupo sulista, conforme enunciado, era a Igreja de Cristo de Santidade, uma denominação que, semelhante à AIPA, da costa Leste dos EUA, foi resultado de diversas uniões de grupos de santidade, a saber: a Igreja de Cristo do Novo Testamento, a Igreja de Santidade Independente e a Missão Pentecostal, cuja união foi consumada em 1905 no Texas, na cidade de Pilot Point.

A Igreja de Cristo do Novo Testamento foi fundada em 9 de julho de 1894 por Robert Lee Harris (? - 1894), um evangelista que empreendeu viagens missionárias ligado à Igreja Metodista Livre (IMEL), mas que acabou se filiando à IME como um evangelista leigo. Harris era um pregador que não estava preso a normas e tradições eclesiásticas, mas que sentia-se contrariado com a postura de vários líderes da IME pela tolerância quanto à jogatina e à frequência de teatros. Somado a essas insatisfações, em novembro de 1893, a conferência de West Tennessee aprovou uma resolução proibindo trabalhos autônomos de evangelistas. A situação piorou quando a Conferência Geral de 1894, que proibiu qualquer pregador ou evangelista metodista de realizar reuniões dos moldes dos camp meetings pregando a doutrina da inteira santificação. Diante dessas situações, Harris se desligou da IME e começou uma série de reuniões e de mensagens restauracionistas na casa da família dos Sheeks, em Memphis, no Tennesee. Em julho de 1893, ele se mudou para a cidade de Milan, no Tennessee, depois de for- 
mar uma parceria de negócios com R. B. Mitchum, que, a essa altura, era pastor Batista. Nesta cidade, ele ergueu uma tenda e iniciou uma série de reuniões de avivamento e santidade, falando sobre "A questão da Igreja". Nessas mensagens, ele denunciava o que ele chamava de "seitas" e outras igrejas que, segundo ele, não estavam compromissadas com a mensagem do evangelho (SMITH, 1962, p. 153-154).

Como esse trabalho de evangelismo foi frutífero, Harris se reuniu com um grupo de aproximadamente 14 pessoas e fundou a nova igreja, cujo o intuito era o de resgatar os valores neotestamentários. Harris faleceu prematuramente, de tuberculose, em 26 de novembro de 1894, antes mesmo da nova denominação completar seus primeiros seis meses. Esse fato abalou os membros da recém-nascida denominação. Mas, depois de muita oração, Mary encorajou-se para assumir a liderança da Igreja de Cristo do Novo Testamento (ICNT). As Sras. Donie Mitchum e Elliot J. Sheeks, juntamente com seus respectivos maridos, R. B. Mitchum e Edwin Sheeks, auxiliaram na nova gestão eclesiástica (RUELAS, 2010, p. 41). Bullón assevera que "o pequeno grupo se estendeu, lentamente, de 1894 a 1901 pelo Oeste do Tennessee, Arkansas, o Norte do Alabama, e partes do Texas, sob a direção de mulheres pregadoras" (BULLÓN, 2011, p. 67).

Outra igreja que nasceu no Sul foi a Igreja de Santidade Independente (ISI), fundada em Junho de 1901 por C. B. Jernigan. Jernigan assumiu a presidência e o jovem evangelista James B. Chapman, a secretaria. A ISI era uma igreja composta por muitas pessoas pobres, mas com o coração desprendido. Eles não tinham dinheiro suficiente nem mesmo para imprimir o Manual da igreja; no entanto, a ajuda mútua possibilitou alcançarem essa finalidade. Jernigan conta o esforço de um homem chamado John C. Tipton, "um homem muito pobre, morando numa fazenda alugada, o qual se ofereceu para vender uma carga de trigo de seu celeiro com a qual ele estava mantendo o seu próprio estoque de farinha familiar", o qual "pagou pela impressão de quinhentas cópias do manual” (JERNIGAN, 1919, p. 79).

Em novembro de 1903, os representantes da Igreja de Cristo do Novo Testamento (ICNT) se reuniram com o Rev. C. B. Jurnigan em Oak Cliff, no Texas. Durante a reunião, os líderes das duas igrejas perceberam que elas eram idênticas em doutrina, e muito semelhantes na política. Deste modo, chegaram a propor uma possível união. No ano seguinte, delegados de ambas as igrejas foram participar das conferências anuais, a fim de expor a proposta e de prosseguirem com a votação para que essa união se efetivasse. Deste modo, a ICNT se reuniu no dia 22 de novembro de 1904, em sua terceira sessão anual em Rising Star, no Texas. [...] O nome escolhido para a nova igreja foi Holiness Church of Christ (Igreja de Cristo de Santidade - ICS) [...] No Conselho Geral seguinte, foi lida uma carta do Rev. C. W. Ruth, que era o 
Vice-Superintendente Geral da Igreja do Nazareno de Bresee. Nesta carta, ele contava a respeito da união que fora proposta entre a Associação de Igrejas Pentecostais da América e a Igreja do Nazareno. A reunião foi convocada em abril de 1906, no Brooklyn. A Igreja de Cristo de Santidade elegeu os pastores R. M. Guy, J. B. Chapman e C. B. Jernigan para participarem como delegados. Contudo, em função de falta de fundos e por ser distante (aproximadamente $2.500 \mathrm{~km}$ ), eles não puderam comparecer, apesar de estarem bastante animados com a proposta. A conversa entre as duas igrejas não cessou, entretanto. Na primeira Assembleia Geral, ocorrida entre os dias 10 a 17 de outubro de 1907, em Chicago, sete delegados da Igreja de Cristo de Santidade - J. P. Roberts, J. Scott, J. Spekes, S. Stafford, C. B. Jernigan, Sra. E. J. Sheeks e o leigo T. J. Shingler - participaram e se animaram ainda mais com a possibilidade de uma nova união (COUTO, 2018b, p. 145-146).

Apesar de a ICS não ter se unido nessa Assembleia de 1907, seus

delegados [...] voltaram bastante entusiasmados para a casa e continuaram a discussão para se unirem à IPN. Foi quando, em 8 de outubro de 1908, a Assembleia Geral da Igreja Pentecostal do Nazareno desceu para o Sul dos EUA e se reuniu em Pilot Point, no Texas, onde a união foi consumada (COUTO, 2018b, p. 146-147).

Nesta segunda Assembleia Geral, o Rev. E. P. Ellyson foi eleito como o terceiro Superintendente Geral, responsável pelas igrejas do Sul dos EUA, ao lado de Phineas Bresee (que era responsável pela costa Oeste) e de Hiram Reynolds (responsável pela costa Leste). ${ }^{3}$

\section{A chegada da Igreja do Nazareno no Brasil}

Atualmente, a Igreja do Nazareno está presente em praticamente 160 países e tem uma membresia total de pouco mais de três milhões de pessoas. Apesar de não ser uma quantidade tão expressiva, sua penetração global gera desafios muito grandes, levando em consideração as grandes transculturalidades. Deste modo, ao atingir tal proporção mundial, foi formalizadas algumas estratégias: "o Secretário Executivo de Missões, E. S. Phillips, recomendou, na Assembleia Geral de 1972, um projeto de internacionalização denominacional". Couto registrou que "a ideia foi bem recebida, de modo que a Assembleia Geral de 1976 autorizou uma Comissão de Internacionalização, que na Assembleia seguinte, 1980, levou a um sistema de regiões mundiais". Sendo assim, "ela está organizada da seguin-

Para conhecer mais acerca da biografia de Reynolds e Ellyson, indico a leitura do livro Uma igreja do povo e para o povo: santidade, irenismo e avivamento na história da Igreja do Nazareno. 
te forma: seis regiões ao redor do mundo (África, Ásia Pacífico, Eurásia, Mesoamérica, América do Sul e EUA/Canadá) e Distritos que reportam administrativamente aos escritórios regionais" (COUTO, 2018b, p. 189).

A chegada ao Brasil se deu em função de algumas pessoas: o Rev. José Zito de Oliveira, a família dos Stegemollers e o Rev. Earl Mosteller.

José Zito (1922-) é natural da ilha de Santo Antão, Cabo Verde. Somente em 1951, depois de insistentes convites de uma parente para que ele visitasse a Igreja do Nazareno, é que ele se converteu a Cristo. Rapidamente ele assumiu algumas atividades na igreja local e, desejando se dedicar ainda mais à obra de Deus, procurou o Rev. Earl Mosteller, que na época era o responsável pela educação teológica dos vocacionados de Cabo Verde. Sua tentativa de iniciar os estudos teológicos em Cabo Verde não foi tão bem sucedida, a grande distância dificultava-lhe conciliar os estudos com o trabalho. Seu desejo de continuar com os estudos fez com que ele tentasse o mesmo caminho de seu parente Joaquim Antônio Lima, que estava estudando em Buenos Aires, na Argentina. No ano de 1956 ele viajou para a Argentina, mas não conseguiu entrar no país em função de as autoridades suspeitarem que ele tivesse algum problema de saúde. Depois de mais algumas tentativas negadas de entrar em Buenos Aires, José Zito se instalou no Brasil, onde passou a congregar na Igreja Presbiteriana Independente de Santo André, pois ainda não existia Igreja do Nazareno em solo brasileiro. Apesar de ter congregado em outra denominação, ele se manteve membro nazareno e enviava o dízimo para sua igreja de Cabo Verde, na Ilha de Santo Antão.

Também em 1956, chegou ao Brasil o casal norte-americano Ervin e Marjorie Stegemoller, que era membro da Igreja do Nazareno de Indianápolis. Ervin veio para o Brasil a trabalho, mas juntamente com sua esposa, enviou cartas para a sede norte-americana, solicitando que fossem enviados missionários para o Brasil, dispondo-se, inclusive, a receber os missionários em sua casa. O Rev. G. B. Williamson, que era superintendente geral, acompanhado do Rev. H. T. Reza, visitou o Brasil e designou, inicialmente, o Rev. Earl Mosteller, que era superintendente em Cabo Verde, para iniciar os trabalhos missionários. Quando ficou sabendo que o missionário designado para o Brasil era o Rev. Mosteller, ficou muito feliz, pois os dois já se conheciam desde Cabo Verde, quando Mosteller fez o possível para lhe ajudar nos estudos teológicos por meio de tutoria à distância. A data do desembarque da família Mosteller, no porto de Santos, foi 31 de julho de 1958 .

Nessa ocasião José Zito conheceu a família dos Stegemoller. Antes de se instalar definitivamente em Campinas, os Mostellers viajaram para 
outros locais brasileiros, a fim de conhecerem melhor o país. Oliveira destaca que eles viajaram "durante seis meses, a Porto Alegre, São Paulo, Santos, Campinas, Rio de Janeiro, Belo Horizonte, Goiânia e Brasília, a fim de escolher o melhor lugar para se instalar a Igreja do Nazareno no Brasil" (OLIVEIRA, 2011, p. 110).

Uma vez decidido que Campinas seria a cidade para iniciar os trabalhos, Mosteller já tinha um aliado: José Zito. Zito ficou bastante animado com a possibilidade de finalmente continuar os estudos e conseguiu, depois de alguns meses, uma transferência da empresa para a cidade de Campinas. Assim, "o primeiro culto foi realizado em 12 de outubro de 1958, na casa de Ervin Stegemoller" e "contou com 12 pessoas, a saber: a família Mosteller (o casal Earl e Gladys e suas três filhas, Kathleen, Virginia e Elizabeth), a família Gates (o casal Charles e Joana) e a família Stegemoller (Ervin, Marjorie e seus três filhos, Ronald, Janis e Carol)" (COUTO, 2018b, p. 199).

As reuniões prosseguiram e cresciam cada vez mais, alcançando o número de quarenta pessoas (BULLÓN, 2011, p. 155). Em função dessa frequência, um amigo lhes ofereceu um imóvel que estava em fase final de construção, localizado numa das principais avenidas de Campinas, a saber, a Francisco Glicério. Depois de uma grande mobilização, em três, semanas tudo estava pronto. "Em 11 de agosto de 1959 inaugurou-se o primeiro templo da Igreja do Nazareno no Brasil" (CUNHA, 2010, p. 57). Para continuar com o projeto de expansão da Igreja do Nazareno no Brasil, outros dois casais missionários foram designados para ajudar o Rev. Mosteller: os Gates, que desembarcaram no porto de Santos no dia 20 de setembro de 1958 e os Denton, que chegaram em 1959. O primeiro casal precisou realizar treinamentos do idioma e da cultura. No período de adaptação eles ajudavam os Mostellers nos trabalhos cúlticos. O segundo casal, por sua vez, já havia servido como missionários em países sul-americanos como Bolívia, Argentina e Uruguai. Por isso, a adaptação para eles foi mais rápida. Com a ajuda do casal Phillip e Ruth Schwab, a Igreja do Nazareno foi inaugurada no dia 30 de outubro de 1959, na Avenida Amazonas. Os Denton assumiram a liderança da igreja e José Zito foi designado como pastor auxiliar.

Em Março de 1960, os Denton foram desafiados a plantar a Igreja do Nazareno em Sobradinho, cidade satélite de Brasília. Com isso, os Gates foram designados para assumir a igreja belo-horizontina. O trabalho continuou prosperando com eles, mas em Junho de 1964, o casal retornou para os Estados Unidos a fim de tirar descanso sabático. A Igreja do Nazareno 
continuou com seus trabalhos de expansão. Além de alcançar a cidade de Campinas, "que se tornou sua cidade base, o missionarismo nazareno estendeu suas tendas a Belo Horizonte, Brasília e a diversas cidades paulistas", de modo que "em 1965 a Igreja do Nazareno já contava com 11 igrejas no Brasil: duas em Campinas, três em Belo Horizonte, uma em Brasília e mais cinco no Estado de São Paulo, sendo uma em Americana, uma em Cosmópolis, uma em Osasco, uma em Santo André e uma em São Paulo" (COUTO, 2018b, p. 207).

Vários outros missionários vieram para o Brasil na década de 1960, dentre eles: Joaquim e Guilhermina Lima (1960-1995), Jaime e Carolina Kratz (1960-1989), Robert e Frances Collins (1962-1998), Roger e Mary Ann Maze (1964-1973), Larry e Dolores Clark (1968-1973). Atualmente, o Brasil possui 19 Distritos, um total de 153.002 membros, 558 igrejas organizadas, 85 missões, 671 presbíteros, 27 diáconos e 668 ministros licenciados.

\section{Conclusão}

Buscou-se com este artigo apresentar informações historiográficas básicas da formação denominacional Igreja do Nazareno numa metodologia exploratória. Não teve por objetivo analisar seu status quo social e teológico; contudo, depois de entender as raízes históricas desta denominação, é possível abrir para este tipo de análise num texto posterior, investigando sua atuação no Brasil e até mesmo comparando sua práxis com a herança anterior. Foi possível perceber que a Igreja do Nazareno é oriunda do movimento de santidade norte-americano e que possui heranças teológicas do wesleyanismo - um movimento que enfatizou a santidade para além da moralidade, num aspecto transformacional - e da pneumatologia modificada pela Sra. Phoebe Palmer, que, influenciada pelo legado fletcheriano, desenvolveu a teologia do Altar. Isso significa dizer que a teologia da perfeição cristã advogada pela Igreja do Nazareno concorda com o pensamento de John Wesley no que tange à natureza e à práxis da santidade. Também significa dizer que foi modificada ao posicionar esta experiência como subsequente à regeneração na via salutis, alinhando-se mais ao posicionamento de John Fletcher. Finalmente, também significa dizer que o posicionamento nazareno se difere completamente do perfeccionismo finneyano, o qual renunciou à doutrina agostiniana do pecado original e resgatou o pensamento pelagiano de perfeição, ou seja, a possibilidade de alcançar a perfeição - num sentido de impecabilidade - na presente vida. 
O presente artigo também visou abordar o processo formativo da denominação num recorte cronológico que se estende apenas às duas primeiras Assembleias Gerais (1907 e 1908) e, posteriormente, nos primeiros anos que se desenvolveu no Brasil. Pôde-se perceber que neste processo a Igreja do Nazareno nasceu de uma proposta irênica e de unidade com alguns grupos do movimento de santidade cuja teologia e práxis se assemelhavam. Este conjunto binário e simbiótico (teologia e práxis/ortodoxia e ortopraxia) fazia parte dos modos de ser dos grupos que se uniram, verificados nos vários engajamentos com os pobres, marginalizados, movimentos pró-abolicionistas, movimentos de temperança e inclusão feminina.

\section{Referências bibliográficas}

BANGS, Carl. Phineas Bresee: pastor to the people. Kansas: Beacon Hill Press, 2013.

BILLMAN, Frank. The supernatural thread in Methodism: signs and wonders among Methodists then and now. Lake Mary: Creation House Press, 2013.

BRICKLEY, Donald. Man of the morning: life and work of Phineas Bresee. Kansas: Nazarene Publishing, 1960.

BULLÓN, Dorothy. História da Igreja do Nazareno. Campinas: CNP, 2011.

COLLINS, Kenneth. Teologia de John Wesley: o amor santo e a forma da graça. Rio de Janeiro: CPAD, 2010.

COUTO, Vinicius. Fé x Obras: ortodoxia e ortopraxia na teologia de John Wesley. São Paulo: Reflexão, 2018a.

COUTO, Vinicius. Uma igreja do povo e para o povo: santidade, irenismo e avivamento na história da Igreja do Nazareno. Campinas: Nazalivros, $2018 \mathrm{~b}$.

COUTO, Vinicius. Uma igreja do povo e para o povo: santidade, irenismo e avivamento na história da Igreja do Nazareno. 2. ed. São Paulo: Reflexão, 2019.

CUNHA, Sandro Hayakawa. Os Oliveiras: vida e pregação de José Zito Oliveira e Zilta Rocha de Carvalho Oliveira. Brasília: [s.n.], 2007.

CUNHA, Sandro Hayakawa. Os Mostellers: vida e pregação de Earl e Gladys Mostellers. Brasília: [s.n.], 2010.

CUNHA, Sandro Hayakawa. Os Gates: vida e pregação de Charles e Joana Gates. Brasília: [s.n.], 2012.

CUNNINGHAM, Floyd. Our watchword \& song: the centennial history of the Church of the Nazarene. Kansas City: Beacon Hill, 2009.

FINNEY, Charles G. Lectures of Systematic Theology. New York: Saxton \& Miles, Volume 1, 1846. 
GIRVIN, E. A. Phineas F. Bresee: a prince in Israel. Kansas City: Nazarene, 1916.

GONZÁLEZ, Justo. Uma história ilustrada do cristianismo: a era dos reformadores até a era inconclusa. V. 2. São Paulo: Vida Nova, 2011.

HALL, Timothy. American religious leaders. New York: Facts on Files, 2003.

HEITZENRATER, Richard P. Wesley e o povo chamado metodista. São Bernardo do Campo; Rio de Janeiro: Editeo; Bennet, 1996.

INGERSOL, Stan. Past and prospect: the promise of Nazarene history. Eugene: Wipf and Stock, 2014.

INGERSOL, Stan. Nazarene Roots. Kansas City: Beacon Hill Press, 2009.

JERNIGAN, Charles Brougher. Pioneer days of the holiness movement in the southwest. Kansas City: Pentecostal Nazarene Publishing House, 1919.

LELIÈVRE, Mateo. João Wesley: sua vida e obra. São Paulo: Vida, 1997.

Manual da Igreja do Nazareno 2017-2021. Campinas: Nazalivros, 2018.

MERRIT, Timothy. What shall be done to revive the work of holiness in the Church?

Guide to Christian Perfection, vol.1, n. 1, 1839, p. 13-23.

NOBLE, Thomas. Trindade santa, povo santo: a teologia da perfeição cristã. Maceió: Sal Cultural, 2015.

OLIVEIRA, Jefferson Rodrigues de. A Igreja do Nazareno: dos primórdios (1895) ao cinquentenário no Brasil (2008). São Bernardo do Campo: Universidade Metodista de São Paulo, 2011. Dissertação de Mestrado.

RASER, Harold E. Phineas Franklin Bresee: recovering the original spirit of Methodism. In: KNIGHT III, Henry H. (Org.). From Aldersgate to Azuza Street: Wesleyan, holiness and Pentecostal visions of the new creation. Eugene: Wipf and Stock Publishers, 2010, p. 167-176.

REDFORD, M. E.; VAN NOTE, Gene. Surge la Iglesia del Nazareno. Kansas: Casa Nazarena de Publicaciones, 2008.

RUELAS, Abraham. Women and the landscape of american higher education: wesleyan holiness and pentecostal founders. Eugene: Wipf and Stock Publishers, 2010.

RUNYON, Theodore. A nova criação: a teologia de João Wesley hoje. São Bernardo do Campo: Editeo, 2002.

SMITH, Timothy. Called unto holiness: church history commission. Kansas: Nazarene Publishing House, 1962.

WESLEY, John. Explicação clara da perfeição cristã. São Bernardo do Campo: Imprensa Metodista, 1984.

WESLEY, John. Obras de Wesley. V. 5. Henrico: Wesley Heritage Foudation, 1996.

Submetido em: 10-7-2019

Aceito em: 19-11-2019 